\title{
STUDY ON THE ORIGIN AND NATURE OF THE ADENOMATOID ODONTOGENIC TUMOR BY IMMUNOHISTOCHEMISTRY
}

\author{
ESTUDO DA ORIGEM E NATUREZA DO TUMOR ODONTOGENICO \\ ADENOMATÓIDE PELA IMUNOISTOQUÍMICA
}

Marcelo Macedo CRIVELINI ${ }^{1}$, Ana Maria Pires SOUBHIA ${ }^{1}$, Renata Callestini FELIPINI²

1- Associate Professor, Department of Oral Pathology, School of Dentistry, State University, Araçatuba, São Paulo, Brazil.

2- Assistant Professor, Department of Oral Pathology, School of Dentistry, State University, Araçatuba, São Paulo, Brazil.

Corresponding address: Marcelo Macedo Crivelini - Rua José Bonifácio, 1193 - Caixa Postal 341 - Araçatuba-SP - BRAZIL

Cep.: 16015-050 - Telephone: 55-18-36363309 - Fax: 55-18-36363332 - E-mail: mmcrivel@foa.unesp.br

Received: August 26, 2004 - Modification: June 09, 2005 - Accepted: October 11, 2005

\begin{abstract}
$T_{\mathrm{h}}$

The adenomatoid odontogenic tumor (AOT) is a clinically benign lesion. Discussions about the AOT hamartomatous or neoplastic nature, and the probable odontogenic epithelial cell it originates from still exist. This research aimed to study and discuss the subject by the immunohistochemical detection of cytokeratins, laminin, collagen IV, PCNA and p53 in 8 tumor samples and 8 dental follicle samples containing reduced enamel epithelium. The results have shown that CK14 labelling indicated differentiation grades for secreting ameloblasts or ameloblasts in the post-secreting stage in the adenomatoid structure of AOT. Laminin, found on the luminal surface of adenomatoid structures, was compatible with the reduced enamel epithelium during the "protective stage of amelogenesis". PCNA specifically labelled the spindled areas and peripheral cords of the AOT, indicating that these areas are responsible for tumor growth. After considerations about pathogenesis, the authors suggested that the nature of AOT is hamartomatous with histogenesis from the reduced enamel epithelium.

Uniterms: Odontogenic neoplasms; Adenomatoid odontogenic tumor; Immunohistochemistry.
\end{abstract}

\section{RESUMO}

O

tumor odontogênico adenomatóide (TOA) é uma lesão clinicamente benigna, cujas discussões acerca de sua natureza hamartomatosa ou neoplásica, e provável célula epitelial odontogênica de origem ainda existem. Este projeto de pesquisa teve por objetivo estudar o assunto através da detecção imuno-histoquímica das citoqueratinas, laminina, colágeno IV, PCNA e p53, utilizando-se para isso 08 amostras do tumor e 08 amostras de folículo pericoronário contendo epitélio reduzido do órgão do esmalte (EROE). Os resultados mostraram que a marcação da CK14 sinalizou graus de diferenciação para ameloblastos secretores ou pós-secretores nas estruturas adenomatóides do TOA, e a laminina presente em sua superfície luminal foi compatível com o EROE durante o "estágio protetor" da amelogênese. O PCNA marcou especificamente áreas enoveladas e cordões periféricos do TOA, indicando serem estes os responsáveis pelo seu crescimento. Após considerações sobre patogênese, os autores propuseram natureza hamartomatosa e histogênese a partir do EROE para o TOA.

Unitermos: Neoplasias odontogênicas; Tumor odontogênico adenomatóide; Imunoistoquímica.

\section{INTRODUCTION}

Originating from dental bud tissues and developing preferably in the dental follicles, the adenomatoid odontogenic tumor (AOT) is undoubtedly accepted as a benign lesion. The issue of its nature being neoplastic or hamartomatous is still object of diverging opinions, generally based on clinical observations and little scientific evidence. Also, there is no consensus regarding the exact histogenesis of the tumor, with suggestions ranging from the dental lamina to the enamel organ as a whole.

In 1975, Courtney and Kerr $^{3}$ believed it was a hamartoma (developmental abnormality) of remnant odontogenic epithelium. Carmo and Silva ${ }^{2}$ (1998) tried to correlate its 
clinical behavior with the cell proliferation rate assessed by AgNOR histochemistry. Philipsen and Reichart ${ }^{14}$ (1999) considered AOT a non-invasive slow-growing benign lesion (hamartomatous). For Takahashi, et al. ${ }^{19}$ (2001) transferrin detection by immunohistochemistry in part of the tumoral cells indicated a neoplastic nature.

There is no doubt about the AOT origin from the odontogenic epithelium; however the cell directly involved in the pathogenesis is still under discussion. Stratum intermedium cells (Okada, et al. ${ }^{13}$, 1987; Montes Ledesma, et al. $\left.{ }^{10}, 1993\right)$, reduced enamel epithelium (Courtney and Kerr ${ }^{3}$, 1975), dental lamina and its remains (Philipsen and Reichart ${ }^{15}$, 1999, Philipsen, et al. ${ }^{16}$, 1992), enamel organ (Hatakeyama and Suzuki ${ }^{7}, 1978$, Schlosnagle and Someren ${ }^{18}$, 1981), undifferentiated odontogenic epithelium or stratum intermedium cells (Tatemoto, et al. ${ }^{22}, 1988$ ) were suggested.

Electron microscopy studies have revealed the interesting presence of hemidesmosomes in the luminal cell membrane of the duct-like and adenomatoid structures, connecting it to a basal lamina-like material. Membranecovered vesicles and granules, with electron-dense central portion, were sometimes interpreted as secretion granules producing intraluminal material (Lee ${ }^{9}$, 1974; Hatakyama and Suzuki $^{7}$, 1978; Schlosnagle and Someren ${ }^{18}$, 1981; Yamamoto, et al. ${ }^{24}$, 1981; Poulson and Greer ${ }^{17}$, 1983; Philipsen and Reichart $\left.^{14}, 1996\right)$.

Few studies in the literature have used the immunohistochemistry technique to analyze AOTs. The most relevant ones detected substances related to amelogenesis, such as enamelysin (Takata, et al. ${ }^{21}, 2000$ ), amelogenin (Murata, et al. ${ }^{11}$, 2000; Abiko, et al. ${ }^{1}$, 2001), sheathlin (Takata, et al. ${ }^{20}$ 2000). Crivelini, et al. ${ }^{4}$ (1996) described laminin on the luminal surface of columnar cells outlining the adenomatoid structures. This finding might resemble the basal lamina next to the internal and external epithelium of the enamel organ, or the surface of the reduced enamel epithelium in the enamel maturation stage. Nagatsuka, et al. ${ }^{12}$ (2002) detected five distinct polypeptide chains of type IV collagen on the eosinophilic hyaline materials.

Based on clinical observations and histochemical, immunohistochemical and ultrastructural findings in literature, we have adopted the hypothesis of AOT being a simple hamartoma, whose histogenesis would be related to the reduced enamel epithelium. Thus, our proposal was to establish the participation of the different polypeptides of cytokeratin, laminin, collagen IV, PCNA, and p53 in the cell and tissue structures of AOT, and to compare it with their expression in the reduced enamel epithelium and with the immunohistochemical reports of the dental buds. This may give support to discussions about the existing hypothesis for tumor pathogenesis and biological nature.

\section{MATERIALS AND METHODS}

Eight adenomatoid odontogenic tumors and 8 dental follicles with reduced enamel epithelium were retrieved from the files of the Oral Pathology Department of the State
University - Araçatuba, Dental School, Brazil.

Paraffin sections of formalin fixed tissue were used for both histological and immunohistochemical evaluation. Hematoxylin-eosin stained sections were made for routine histological examination. For immunohistochemical technique, 3- $\mu \mathrm{m}$ tissue sections were deparaffinized and treated with citric acid (10mM, pH 6.0) three times for $5 \mathrm{~min}$. at $700 \mathrm{~W}$ in a microwave oven. Two incubations ( $5 \mathrm{~min}$. each) with $0.6 \%$ hydrogen peroxide in methanol were made in order to block endogenous peroxidase activity, followed by washing with TRIS pH 7.4. Primary antibodies were then incubated; their sources, concentrations, and times of incubation are listed in Table 1. After this procedure, sections were thoroughly washed with TRIS pH 7.4 and incubated for 20 min. using Universal Large Volume DAKO LSAB ${ }^{\circledR}+$ Kit, a biotinylated link antibody that labels primary antibodies produced in rabbit, mouse or goat. The color reaction was developed using a freshly prepared solution of 3,3diaminobenzidine tetrahydrochloride for $3 \mathrm{~min}$. Finally Mayer's hematoxylin was used for counterstaining. Data were scored by observing the presence of a brown end product at the site of the target antigen under a light microscope. Positive controls for each CK and vimentin were used as indicated by the supplier, which labelled, in normal tissues, the following: CK7, 18, 19 (glandular epithelia), CK 10, 13 (suprabasal cells of epidermis), CK 14 (basal cells of epidermis), and vimentin (endothelial cells). Replacing the primary antibody with TRIS performed negative controls.

\section{RESULTS}

Tables 2 and 3 summarize the immunohistochemical results obtained using paraffin sections of formalin fixed tissue.

\section{Adenomatoid odontogenic tumor}

The adenomatoid odontogenic tumors presented epithelial proliferation in which cells placed in solid nodules forming sheets, or a nest-and cord-like pattern. In the solid nodules, cells were ovoid and cylindrical, the latter outlining duct-like structures, which contained homogeneous eosinophilic material in the center. Sometimes the eosinophilic material showed linear configuration, also outlined by cylindrical cells. Adenomatoid structures were generally present, which were round with a much wider diameter than the duct-like structures and outlined by low or tall columnar cells. Not rarely did these structures present a thin layer of the eosinophilic material in its internal surface. Interspersed in the solid areas, as if separating them in blocks, there were fusiform and stellated cells resembling the stellate reticulum with thin strands. Small cuboid or polyhedrical cells formed peripheral cords that sometimes seemed to fold and overlap, forming compact sheets. In one of the tumors, occasional cell foci with a squamous appearance were observed. Mineralized structures resembling Liesegang rings, dystrophic calcification areas, 
and other small intercellular eosinophilic hyaline deposition, with shapeless light or dark pinkish appearance, sometimes lamellar and concentric were present. Adjacent to the tumoral proliferation, a cystic lining formed by stratified pavement epithelium was common. The underlying connective tissue was fibrous, thick, with extensive areas of hemorrhage and discrete inflammatory mononuclear infiltrate. In the vicinities of the tumor, blood capillary vessels with perivascular hyalinization, and delicate connective tissue rich in ground substance were noted.

In the immunohistochemical staining, tumoral epithelial cells were not positive for cytokeratins $7,13,18,19$, vimentin and p53. CK14 was detected in the cords of cubic and peripheral polyhedrical cells, as well as in the fusiform and stellated cells adjacent to the solid areas of the tumor. Cells forming the adenomatoid structures and the solid areas were not positive in two of the samples and varied in the others (Figure 1). An expression pattern opposite to CK14 was observed in the detection of PCNA. It labelled, from weakly to strongly, most of the cells in the solid areas, adenomatoid structures, cords of cubic and polyhedrical cells, and was practically absent or weak in the fusiform cells and in the stellated cells interspersed in the solid areas (Figure 2).

The immunohistochemical analysis showed positive results for laminin in the luminal surface of the cells bordering the adenomatoid structures, in the small intercellular deposits of lighter eosinophilic material interspersed in the epithelial proliferation of spindled areas and cords, and on the borders between the tumor and connective tissue (Figure $3)$. The material corresponding to darker eosinophilc was negative for laminin. Collagen IV had discrete expression only in the zone of the basal membrane of a few tumors; however, around the neighboring stromal capillary vessels it was noteworthy.

\section{Reduced enamel epithelium}

The samples of pericoronal flap presented pavement stratified reduced enamel epithelium, with two or three cell layers and, in one of the samples, cubic basal cells and columnar superficial cells, resembling post-secretory ameloblasts.

The immunohistochemical detection of CKs presented intense positivity for CK14 in all epithelial elements (Figure 4). The expression was variable for CK13, labelling occasional disperse cells, generally superficial (Figure 5). Weak expression in this same pattern characterized CK19, in three samples. The results for CK7, 18, vimentin, and p53 were negative. Laminin was clearly expressed in the zone of the basal membrane, both of the epithelium and of the blood vessels, a pattern that was followed by collagen IV; however, with weaker expression, not rarely absent next to the epithelium. PCNA was expressed mainly in the basal epithelial cell nuclei and in some of the suprabasal cells. The epithelium with columnar cells followed this pattern, with rare positive suprabasal cells (Figure 6). Epithelia in inflammatory areas presented disperse positivity.

\section{DISCUSSION}

As previously said, we focused on the ultrastructural detail of the presence, in the luminal surfaces of the adenomatoid structures, of hemidesmosomes and a material similar to the basal lamina, confirmed histochemically by the presence of laminin. Such characteristics are similar to those of the reduced enamel epithelium (REE) in the protective and maturation stage of amelogenesis, which led us to work on the hypothesis of the origin of AOT from it. It is known that at the end of amelogenesis, post-secretory ameloblasts synthesize a material similar to the basal lamina, which adheres to the newly formed enamel. This stage is called "protective stage of amelogenesis", which avoids cementoblastic differentiation in the follicle and cementum deposition (or “osteodentin”) next to the enamel (Ten Cate ${ }^{23}$, 1994).

This would justify the capability of AOT cells to secrete enamel matrix proteins, such as amelogenin or enamelin shown in the immunohistochemical reactions of Murata, et al. ${ }^{11}$ (2000). We can consider in our hypothesis of AOT origin

TABLE 1- Monoclonal antibodies used

\begin{tabular}{|c|c|c|c|c|}
\hline Antibodies & Clone & Concentration & Incubation time (min) & Temperature \\
\hline $\mathrm{CK} 7^{\mathrm{a}}$ & OV-TL 12/30 & $1: 150$ & 60 & room \\
\hline CK10-13 ${ }^{a}$ & DE-K13 & $1: 150$ & 60 & room \\
\hline $\mathrm{CK} 14^{\mathrm{a}}$ & LL002 & $1: 500$ & 60 & room \\
\hline CK18 ${ }^{a}$ & DC10 & $1: 50$ & 60 & room \\
\hline CK19a & RCK108 & $1: 75$ & 60 & room \\
\hline Vimentin $^{\mathrm{a}}$ & VIM3B4 & $1: 300$ & 60 & room \\
\hline Laminin $^{b}$ & LAM-89 & $1: 200$ & 120 & room \\
\hline Collagen IV & CIV 22 & $1: 100$ & 120 & room \\
\hline PCNA ${ }^{a}$ & PC10 & $1: 300$ & 120 & room \\
\hline p53 ${ }^{a}$ & DO-7 & $1: 75$ & 60 & room \\
\hline
\end{tabular}

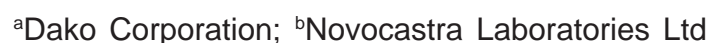


from the REE that the cells in that epithelium had been recently active, producing enamel matrix in the amelogenesis and that some of them might still keep the capacity of synthesis and secretion when forming the AOT. Corroborating this idea is the known influence of the REE on the modifications

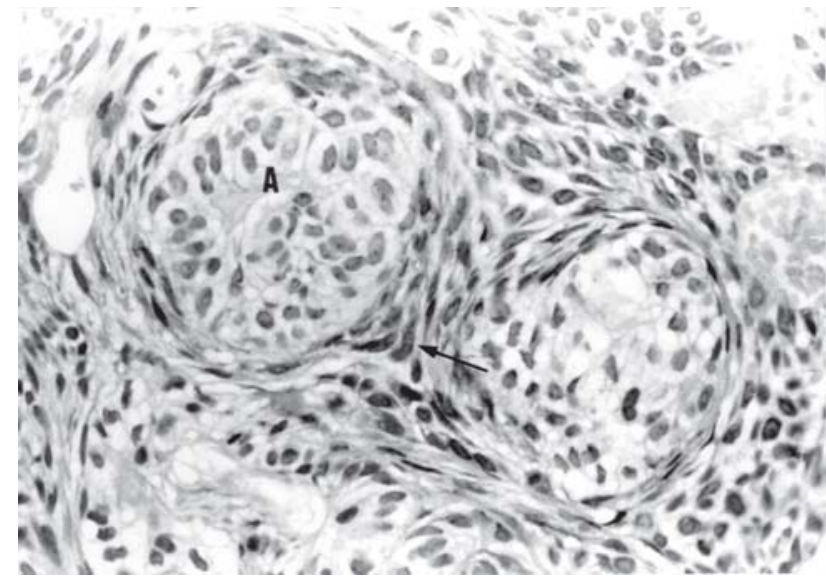

FIGURE 1- Adenomatoid odontogenic tumor: CK 14 citoplasmic positivity only in the fusiform and stellated cells (arrow) adjacent to the solid nodules (A). X400

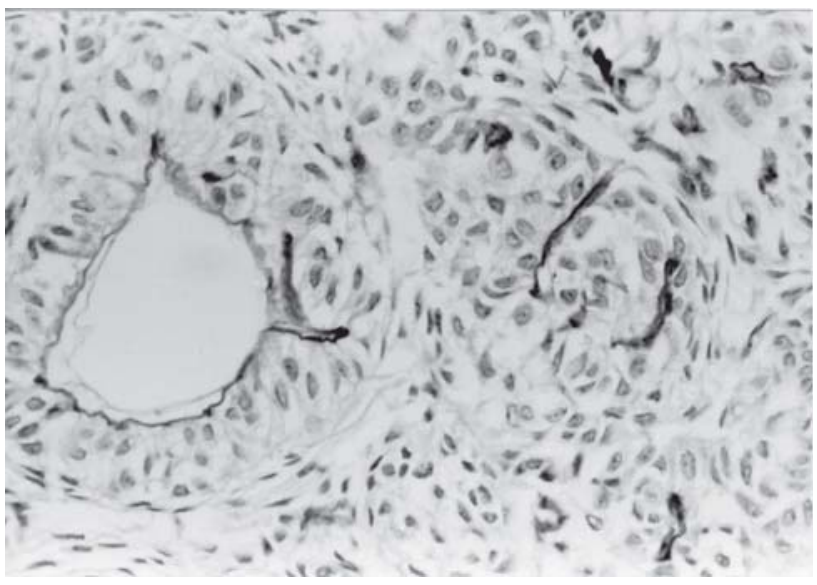

FIGURE 3- Adenomatoid odontogenic tumor: laminin in the intercellular deposits and luminal surface of adenomatoid structures. X200

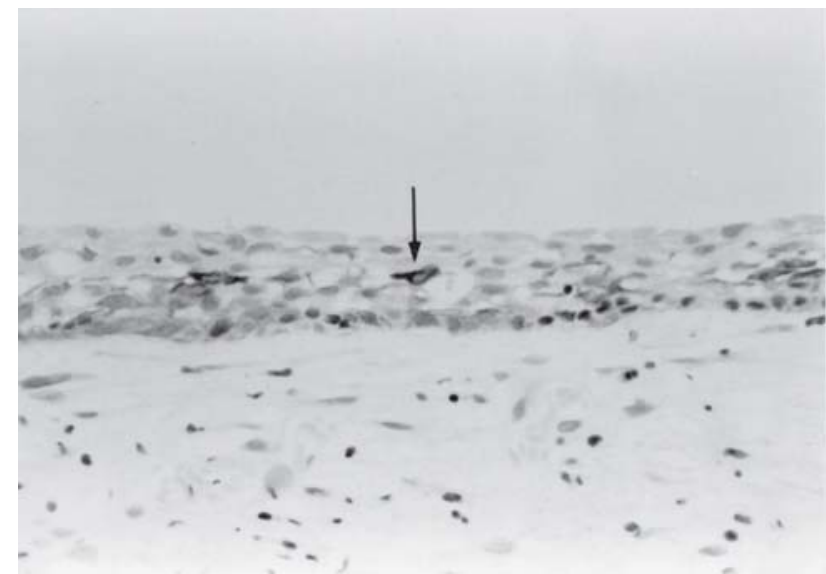

FIGURE 5-Reduced enamel epithelium: Detection of CK13 in disperse cells (arrow). X400 in the composition of enamel after amelogenesis, in normal conditions, which does not play only the protective role (Ten Cate ${ }^{23}$, 1994). We believe that AOT cells might be able to secrete two types of substances, according to their functional capability: basal membrane material or enamel

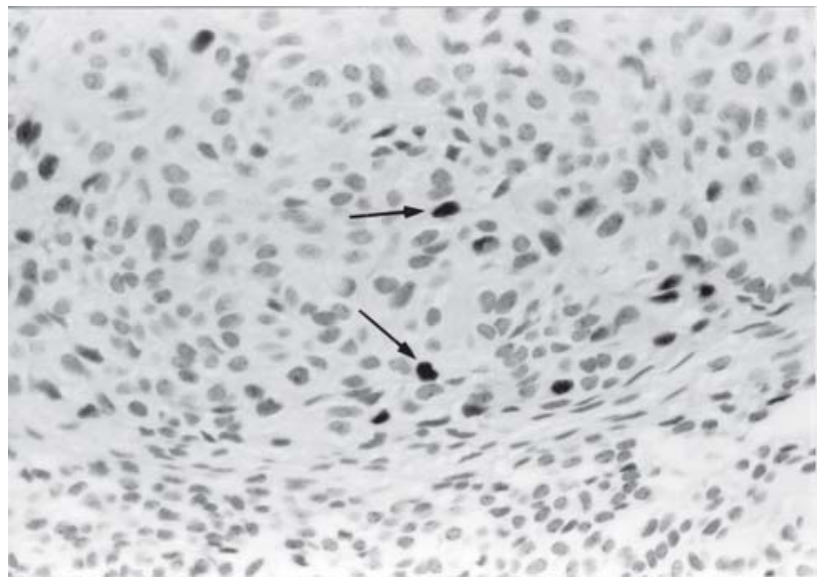

FIGURE 2-Adenomatoid odontogenic tumor: strong nuclear expression of PCNA restricted at solid areas (arrows), oppositing CK14 results. X400

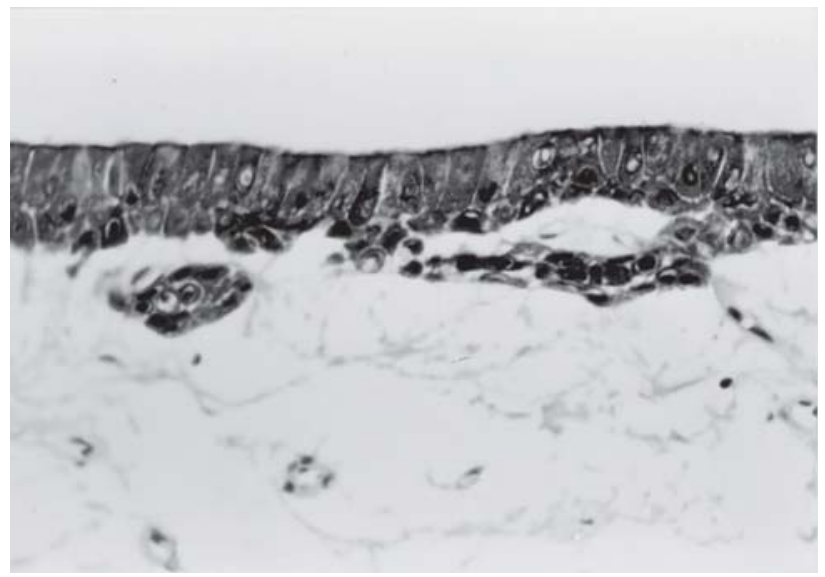

FIGURE 4- Reduced enamel epithelium: All cells exhibiting CK14. X400

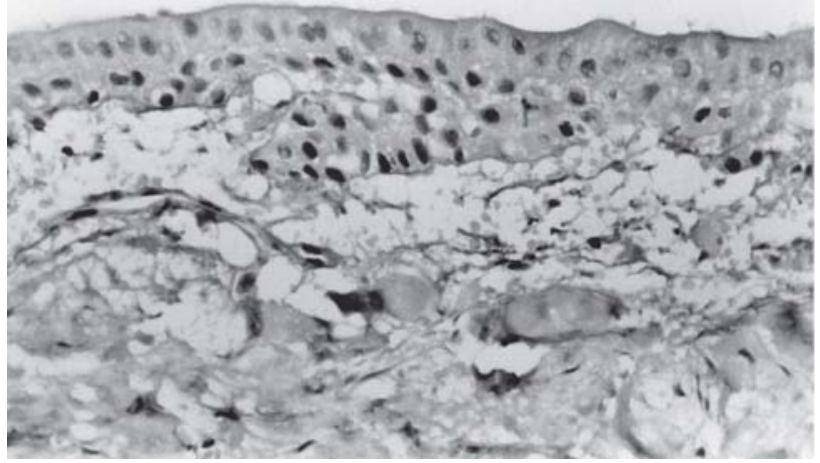

FIGURE 6- Reduced enamel epithelium: nuclei of basal cells darker due to PCNA expression. X400 
matrix. The distinction between these two substances in the routine hematoxylin and eosin staining is possible. We described in our results the presence of eosinophilic material in small intercellular deposits, with a shapeless pinkish aspect either lighter or darker, sometimes lamellar, both disperse in the epithelial sheets of the AOT. The former was immunohistochemically positive for laminin, therefore, representing substance of the basal membrane. The latter did not express laminin and apparently was prone to mineralization, and probably corresponded to the material positive to enamel protein in the study of Takata, et al. ${ }^{20,21}$ (2000).

As the AOT is an epithelial tumor, it is interesting to analyze histochemically the different types of cytokeratins in it. Domingues, et al. ${ }^{6}$ (2000) described the distribution of the subtypes of intermediate filaments in the dental buds. They emphasised CK 14 present in the inner epithelium of the enamel organ in the early bell stage, which was posteriorly substituted by CK19, when the ameloblasts were completely differentiated. We had an interesting CK14 immunohistochemical profile. In some of the samples, it labelled only cells between the spindled and duct-like structures, distinguishing two cell populations. The spindled areas and the cylindrical cells of the duct-like structures did not express it. So, the variation in the expression of CK14 indicated variable differentiations of the tumoral cells. The spindled structures, where the duct-like and adenomatoid structures were located, would form a cell group analogous to post-secretory ameloblasts of the reduced enamel epithelium, surrounded by a second group, constituted by flat fusiform cells, sometimes with morphology similar to that of the stellate reticulum. If we consider the cubic cells of the duct-like and adenomatoid structures analogous to post-secretory ameloblasts in their early stage, still capable

TABLE 2- Immunohistochemical staining of epithelial components of adenomatoid odontogenic tumor by monoclonal antibodies directed against different substances

\begin{tabular}{|c|c|c|c|c|c|c|c|c|c|c|}
\hline Antibodies & CK7 & CK13 & CK14 & CK18 & CK19 & Vimentin & Laminin & Collagen IV & PCNA & p53 \\
\hline $\begin{array}{l}\text { Histological } \\
\text { structure }\end{array}$ & & & & & & & & & & \\
\hline Solid nodules & - & - & $+/-$ & - & - & - & - & - & + & - \\
\hline Duct-like structures & - & - & $+/-$ & - & - & - & - & - & + & - \\
\hline Adenomatoid structures & - & - & $+1-$ & - & - & - & - & - & + & - \\
\hline $\begin{array}{l}\text { Flatted and stellated cells } \\
\text { Peripheral cords of cubic }\end{array}$ & - & - & + & - & - & - & - & - & - & - \\
\hline $\begin{array}{l}\text { or polyhedrical epithelial cells } \\
\text { Lighter homogeneous }\end{array}$ & - & - & + & - & - & - & - & - & - & - \\
\hline $\begin{array}{l}\text { eosinophilic material } \\
\text { Darker homogeneous }\end{array}$ & - & - & - & - & - & - & + & - & - & - \\
\hline eosinophilic material & - & - & - & - & - & - & - & - & - & - \\
\hline Calcified bodies & - & - & - & - & - & - & - & - & - & - \\
\hline Basal lamina & - & - & - & - & - & - & + & + & - & - \\
\hline
\end{tabular}

+, positive; -, negative; +/-, weak positive

TABLE 3- Immunohistochemical staining of reduced enamel epithelium of dental follicles by monoclonal antibodies directed against different substances

$\begin{array}{llllllll}\text { Antibodies } & \text { CK7 } & \text { CK13 } & \text { CK14 } & \text { CK18 } & \text { CK19 Vimentin Laminin } & \text { Collagen IV PCNA } & \text { P53 }\end{array}$

\section{Histological}

structure

\begin{tabular}{|c|c|c|c|c|c|c|c|c|c|c|}
\hline Cylindrical upper cells & - & $+^{*}$ & + & - & $+/-*$ & - & - & - & $+* \star$ & - \\
\hline Squamous cells & - & $+*$ & + & - & $+1-*$ & - & - & - & $+* *$ & - \\
\hline Basal cells & - & $+^{*}$ & + & - & $+/-*$ & - & - & - & + & - \\
\hline Basal lamina & - & - & - & - & - & - & + & + & - & - \\
\hline
\end{tabular}

*Occasional and disperse cells; **rare cells (+, positive; -, negative; +/-, weak positive) 
of secreting some enamel protein, the tendency for absence of CK14 is understandable because this also occurred in normal ameloblasts. From the moment at which the cells no longer have their secretory function, CK14 is expressed again. This justifies the expression in all epithelial cell elements of other AOTs and in the REE, regardless of the histological characteristics.

Laminin was clearly present in the luminal surface of the adenomatoid structures and in the lighter eosinophilic intercellular deposits, either focal or linear, which is compatible with the surface of the reduced enamel epithelium during the protective stage of amelogenesis. Nevertheless, in our REE samples, laminin was not detected in the epithelial surface, probably because the REE in the samples are associated to dentigerous cyst, which would modify its expression. Type IV collagen was restricted to the interface between tumor epithelium and stroma. Nagatsuka, et al. ${ }^{12}$ (2002) obtained analogous results with $\alpha 1(\mathrm{IV}) / \alpha 2(\mathrm{IV})$ and $\alpha 5(\mathrm{IV}) / \alpha 6(\mathrm{IV})$ polypeptide chains of type IV collagen. Nevertheless, the authors believed that some cells of AOT (cribriform areas) would resemble dental lamina (primitive cells), while others would be histodifferentially more mature (secretory phase of odontogenesis), due to $\alpha 4$ (IV) chain expression had ocurred on the cribriform areas and hyaline materials.

PCNA results in the REE were as expected, with expression restrict to the basal or suprabasal cells or cells scattered in areas in which subepithelial inflammation was present. In the AOT, PCNA revealed that the cells in the spindled areas and in the peripheral cords were the most proliferative, which could suggest that those sites would be responsible for the tumoral growth. We could justify the absence of the typical adenomatoid structures in the solid nodules forming sheets because they could have disappeared for having been gradually compressed by the tumoral mass as it evolved. The large adenomatoid structures, resulting from the circular (tridimensional, "tubular") configuration of the columnar cells and cylindrical superficial cells of the REE due to its hamartomatous growth, would be formed in recent tumors, right from their onset. They would gradually decrease, however, due to compression of the tumoral mass as it grew. The specific PCNA cell labelling in the AOTs, not present in the flat and stellate cells among the spindled areas, helped to rule out a neoplastic nature for the tumor.

As far as the extrafollicular variant, we agree with Philipsen, et al. ${ }^{16}$ (1992) concerning the possibility of a tooth erupting through the AOT. The hamartomatous lesion would start at the REE and occasionally would not hinder dental eruption. We would also emphasize that the AOT could remain intraosseous or peripheral in the jaw bones, depending on the spatial position of the tumor and associated tooth. In deeper impacted teeth, there would be more possibility of TOA to be intraosseous follicular or extrafollicular (in the case of tooth eruption) lesion. In tooth impactions next to the alveolar ridge, the tumor could occasionally involve the gingiva during or after the eruption process, which would justify the peripheral variant.
The interesting dysplastic dentin microscopic picture has led the World Health Organization (WHO) to classify the AOT in the group of neoplasias and other tumors related to the odontogenic apparatus, benign subgroup composed by odontogenic epithelium with ectomesenchyme in the Histological Typing of Odontogenic Tumors (Kramer, et al. , 1992). We could accept the rare formation of osteodentin next to the AOT, but as secondary phenomenon in the tumor pathogenesis. If we had previously considered that the AOT produces enamel matrix in some areas, this matrix, when in contact with stromal connective tissue, would trigger mesenchymal induction in the same way as the phenomenon reported by Ten Cate ${ }^{23}$ (1994) in the "protective stage of amelogenesis", in which there is osteodentin or cementum production on the enamel surface by differentiation of dental follicle cells. With these arguments, we discuss if it wouldn't be better to classify AOT as "neoplasias and other tumors related to the odontogenic apparatus, benign subgroup composed by odontogenic epithelium without odontogenic ectomesenchyme”.

\section{ACKNOWLEDGEMENTS}

FAPESP - Fundação de Amparo à Pesquisa do Estado de São Paulo (proc. 00-03112-4)

\section{REFERENCES}

1- Abiko Y, Murata M, Ito Y, Taira T, Nishimura M, Arisue M, Inoue T, Shimono M, Kuboki Y, Kaku T. Immunohistochemical localization of amelogenin in human odontogenic tumors, using a polyclonal antibody against bovine amelogenin. Med Electron Microsc. 2001;34:185-9.

2- Carmo MA, Silva EC. Argyrophilic nucleolar organizer regions (AgNORs) in ameloblastomas and adenomatoid odontogenic tumors (AOTs). J Oral Pathol Med. 1998;27:153-6.

3- Courtney RM, Kerr DA. The odontogenic adenomatoid tumor. A comprehensive study of twenty new cases. Oral Surg Oral Med Oral Pathol. 1975;39:424-35.

4- Crivelini MM, Orsini SOM, Raitz R, Santos E. Detecção imunohistoquímica da laminina e colágeno tipo IV nos tumores odontogênicos. In: Anais da 13a Reunião Científica da Sociedade Brasileira de Pesquisa Odontológica-SBPqO; 1996 set 01-04; Águas de São Pedro (SP). São Paulo: SBPqO; 1996. p. 181, resumo 291.

5- Crivelini MM, Araújo VC, Sousa SOM, Araújo NS. Cytokeratins in epithelia of odontogenic neoplasms. Oral Dis. 2003;9:1-6.

6- Domingues MG, Jaeger MM, Araújo VC, Araújo NS. Expression of cytokeratins in human enamel organ. Eur J Oral Sciv. 2000;108:43-

7- Hatakeyama S, Suzuki A. Ultrastructural study of adenomatoid odontogenic tumor. J Oral Pathol. 1978;7:295-300.

8- Kramer IR, Pindborg JJ, Shear M. The WHO histological typing of dontogenic tumors: a commentary on the second edition. Cancer. 1992;70:2988-94

9- Lee KW. A light and electron microscopic study of the adenomatoid odontogenic tumor. Int J Oral Surg. 1974;3:183-93. 
10- Montes Ledesma C, Mosqueda Taylor A, Romero de León E, De la Piedra Garza M, Jaukin PG, Robertson JP. Adenomatoid odontogenic tumor with features of calcifying epithelial odontogenic tumor. (The so-called combined epithelial odontogenic tumor) Clinico.pathological report of 12 cases. Eur J Cancer B Oral Oncol. 1993;29B:221-4.

11- Murata M, Cheng J, Horino K, Hara K, Shimokawa H, Saku T. Enamel proteins and extracellular matrix molecules are co-localized in the pseudocystic stromal space of adenomatoid odontogenic tumor J Oral Pathol Med. 2000;29:483-90.

12- Nagatsuka H, Siar CH, Nakano K, Tsujigiwa H, Gunduz M, Choufuku H, Lee YJ, Naito I, Sado Y, Nagai N. Differential expression of collagen IV á1 to á6 chains in basement membranes of benign and malignant odontogenic tumors. Virchows Arch. 2002;441:392-9.

13- Okada Y, Mochizuky K, Sugimura M, Noda Y, Mori M. Odontogenic tumor with combined characteristics of adenomatoid odontogenic and calcifying epithelial odontogenic tumors. Pathol Res Pract. 1987;182:647-57.

14- Philipsen HP, Reichart PA. The adenomatoid odontogenic tumor: ultrastructure of tumor cells and non-calcified amorphous masses. J Oral Pathol Med. 1996;25:491-6.

15- Philipsen HP, Reichart PA. Adenomatoid odontogenic tumor: facts and figures. Oral Oncol. 1999;35:125-31.

16- Philipsen HP, Samman N, Ormiston IW, Wu PC, Reichart PA. Variants of the adenomatoid odontogenic tumor with a note on tumor origin. J Oral Pathol Med. 1992;21:348-52.

17- Poulson TC, Greer, RO. Adenomatoid odontogenic tumor: clinicopathologic and ultrastructural concepts. J Oral Maxillofac Surg. 1983;41:818-24.

18- Schlosnagle DC, Someren A. The ultrastructure of the adenomatoid odontogenic tumor. Oral Surg Oral Med Oral Pathol. 1981;52:154-61.

19- Takahashi H, Fujita S, Shibata Y, Yamagushi A. Adenomatoid odontogenic tumor: immunohistochemical demonstration of transferrin, ferritin and alpha-one-antitrypsin. J Oral Pathol Med. 2001;30:237-44

20- Takata T, Zhao M, Uchida T, Kudo Y, Sato S, Nikai H. Immunohistochemical demonstration of an enamel sheath protein, sheatlin, in odontogenic tumors. Virchows Arch. 2000;436:324-9.

21- Takata T, Zhao M, Uchida T, Wang T, Aoki T, Bartlett JD, Nikai H. Immunohistochemical detection and distribution of enamelysin (MMP-20) in human odontogenic tumors. J Dent Res. 2000;79:160813.

22- Tatemoto Y, Tanaka T, Okada Y, Mori M. Adenomatoid odontogenic tumor: co-expression of keratin and vimentin. Virchows Arch A Pathol Anat Histopathol. 1988;413:341-7.

23- Ten Cate AR. Oral histology: development, structure, and function. 4. ed. St. Louis: Mosby; 1994. p.147-238.

24- Yamamoto H, Kozawa Y, Hirai G, Hagiwara T, Nakamura T. Adenomatoid odontogenic tumor: light and electron microscopic study. Int J Oral Surg. 1981;10:272-8. 